\title{
THE ROLE OF THE ANTERIOR PITUITARY IN THE CONTROL OF ALDOSTERONE SECRETION IN EXPERIMENTAL SECONDARY HYPERALDOSTERONISM *
}

\author{
By JAMES O. DAVIS, NICHOLAS A. YANKOPOULOS, FEROL LIEBERMAN, \\ JOHN HOLMAN AND ROBERT C. BAHN WITH THE SURGICAL ASSISTANCE OF \\ ALFRED CASPER \\ (From the Section on Experimental Cardiovascular Disease, Laboratory of Kidney and \\ Electrolyte Metabolism, National Heart Institute, Bethesda, Md. and from \\ the Section of Pathological Anatomy, Mayo Clinic, Rochester, Minn.)
}

(Submitted for publication September 25, 1959; accepted January 8, 1960)

Previous reports (1-9) have delegated a secondary role to anterior pituitary hormones in the control of aldosterone secretion. ${ }^{1}$ Although hypophysectomy resulted in decreased aldosterone secretion (3) or reduced urinary aldosterone output (2), hyperaldosteronuria, marked sodium $(\mathrm{Na})$ retention and ascites occurred in the absence of the adenohypophysis in dogs with thoracic inferior vena cava constriction (2). Also, in patients with hypopituitarism, Luetscher and Axelrad (6) and Hernando and associates (7) found that urinary aldosterone output was within normal limits in some patients on an unselected diet or a normal salt intake, and Liddle, Duncan and Bartter (8) reported hyperaldosteronuria in one patient with hypopituitarism on a low $\mathrm{Na}$ diet.

However, no conclusive evidence of hypersecretion $^{1}$ of aldosterone in the absence of anterior pituitary hormones has been reported. The critical pertinent data on the rate of aldosterone secretion during stimulation which produces hypersecretion in normal animals have not been reported for hypophysectomized dogs or patients. It is important that studies in man be conducted on hypophysectomized patients since patients with so-called panhypopituitarism may not have loss of all anterior pituitary function. Furthermore, our knowledge is incomplete on the importance of specific anterior pituitary hormones. Several studies $(3,7,8-10)$ have demonstrated an increase in aldosterone secretion or urinary aldo-

* This investigation was aided in part by Grant A-1944 from the National Institutes of Health, Bethesda, Md.

1 The phrases "aldosterone secretion" or "hypersecretion of aldosterone" have been used to refer to actual measurements of the rate of secretion by the adrenal gland into the effluent plasma and are to be distinguished from urinary aldosterone excretion. sterone excretion following administration of various corticotropin preparations, but the data are inadequate to establish the role of $\mathrm{ACTH}$ in secondary hyperaldosteronism. ${ }^{2}$

The question of the role of the anterior pituitary in the control of aldosterone secretion was reopened by the finding of a 76 to 97 per cent fall in adrenal vein aldosterone output following hypophysectomy of dogs with experimental secondary hyperaldosteronism (11). In the present report, data are presented on the efficacy of $\mathrm{ACTH}^{3}$ in preventing this fall in aldosterone secretion which follows hypophysectomy. Large doses of cortisone have been administered to inhibit ACTH secretion in dogs with hyperaldosteronism secondary to caval constriction; the resultant effects on aldosterone and corticosterone production were observed. Subsequently, the effects of hypophysectomy and ACTH were studied in these animals. Also, the effects of synthetic $\alpha$-melanophore-stimulating hormone (MSH) and of highly purified preparations of natural $\alpha$ - and $\beta$-MSH have been studied. Attempts have been made to stimulate hypersecretion of aldosterone in simple hypophysectomized dogs by 1) a low $\mathrm{Na}$ diet and 2) acute constriction of the thoracic inferior vena cava.

\footnotetext{
2 In this paper the trivial names of the steroids have been used: cortisone $(17 \alpha, 21$-dihydroxy-4-pregnene-3,11,20 -trione) ; corticosterone (11 $\beta, 21$-dihydroxy-4-pregnene3,20-dione); 11 -dehydrocorticosterone (21-hydroxy-4pregnene-3,11,20-trione); aldosterone (11 $\beta, 21$-dihydroxy18-aldo-4-pregnene-3,20-dione); cortisol (11 $\beta, 17 \alpha, 21$-trihydroxy-4-pregnene-3,20-dione); and 2-methyl cortisol ( $2 \alpha$-methyl-11 $\beta, 17 \alpha, 21$-trihydroxy-4-pregnene-3,20-dione).

3 Subsequent reference will be made to ACTH or to an ACTH preparation; it is recognized that contaminating substances with ACTH-like activity may be present.
} 


\section{METHODS}

The 26 animals used in this study were 15 to $20 \mathrm{~kg}$ mongrel dogs. Nine animals were dogs with chronic experimental hyperaldosteronism and ascites secondary to constriction of the thoracic inferior vena cava (12); urinary $\mathrm{Na}$ excretion was less than $5 \mathrm{mEq}$ per day on a $\mathrm{Na}$ intake of $60 \mathrm{mEq}$ per day. The other 17 animals were simple hypophysectomized dogs at the onset of the experiment. In Experiment 1, the efficacy of ACTH in blocking the usual striking fall in aldosterone and corticosterone secretion which follows hypophysectomy was studied. In Experiment 2, large daily intramuscular doses of cortisone acetate $(100 \mathrm{mg}$ to $4 \mathrm{dogs}$ and 200 $\mathrm{mg}$ to 3 dogs) were given for 8 days except that in the 3 animals receiving $200 \mathrm{mg}$ daily, $100 \mathrm{mg}$ of the cortisone was given orally on the last day. On the last day of cortisone administration, adrenal vein aldosterone and corticosterone output was measured. Five of the 7 dogs receiving cortisone were hypophysectomized after the 3 initial observations on steroid secretion; subsequently, in 4 of these 5 dogs the effects of ACTH were evaluated. In Experiment 3, preparations of $\alpha$ - and $\beta$-MSH were assayed in 4 simple hypophysectomized dogs. In Experiment 4, 10 simple hypophysectomized dogs were placed on a low $\mathrm{Na}$ diet for 7 to 19 days; for 5 of the dogs, $\mathrm{Na}$ intake was $7 \mathrm{mEq}$ per day, whereas the other 5 animals received $1 \mathrm{mEq}$ per day of $\mathrm{Na}$. Potassium intake was $40 \mathrm{mEq}$ per day. After acute adrenal vein aldosterone and corticosterone measurements in these hypophysectomized dogs on a low $\mathrm{Na}$ intake, the effects of ACTH were studied in 4 animals. In 3 additional dogs, the anterior pituitary was removed and after 2 hours the thoracic inferior vena cava was constricted acutely in an attempt to stimulate the adrenal cortex.

The same dose and preparation of ACTH were used in all experiments; 0.075 unit per minute of an Upjohn preparation was given intravenously in 5 per cent glucose at a rate of $0.62 \mathrm{ml}$ per minute of solution with a constant infusion pump into the left subclavian vein. Synthetic $\alpha-\mathrm{MSH}$ was prepared and supplied to us by Dr. Klaus Hofmann. This synthetic preparation is like the natural hormone except that glutamic acid is in the form of glutamine, and lysine is in the form of $\epsilon$-formyllysine. The synthetic preparation was assayed by Dr. Aaron B. Lerner and found to have $6.6 \times 10^{8}$ units of MSH activity per mg. Highly purified preparations of $\alpha$ - and $\beta$-MSH from hog anterior pituitary were provided by Doctors Aaron $\mathrm{B}$. Lerner and Teh $\mathrm{H}$. Lee. The MSH potency of the natural $\alpha-\mathrm{MSH}$ preparation was $2.8 \times 10^{6}$ units per $\mathrm{mg}$, whereas the $\beta$-MSH preparation had $2.6 \times 10^{6}$ units of activity per mg. The MSH preparations were dissolved in 5 per cent glucose and infused at the rate of $0.62 \mathrm{ml}$ per minute over a 30 minute period.

Observations on aldosterone and corticosterone secretion in adrenal vein plasma were made at 30 to 60 minute intervals in animals under light Nembutal anesthesia. The dogs received 100 per cent oxygen through an endotracheal tube attached to a pneophore at a pressure of 10 to $15 \mathrm{~cm}$ water. The right adrenolumbar vein was cannulated and measurements of adrenal blood flow were made by techniques described previously (13). Ten or $20 \mathrm{ml}$ of adrenal vein blood and $10 \mathrm{ml}$ of peripheral blood were removed for each group of analyses; normal donor blood was injected immediately to replace the blood removed for analysis. Urinary $\mathrm{Na}$ was measured by flame photometry. Cardiovascular pressures were measured in the abdominal aorta and inferior vena cava with Statham strain gages and a Sanborn recording system. An infusion of norepinephrine $(100 \mu \mathrm{g}$ per $\mathrm{ml})$ was given to 3 of the hypophysectomized dogs on a low $\mathrm{Na}$ diet (Dogs 4, 6 and 8) during the latter part of the experiment to maintain arterial pressure and adrenal blood flow.

The concentrations of aldosterone and corticosterone in adrenal vein plasma were measured by the double isotope derivative procedure as described previously (14), with one exception; a third chromatography was used to purify corticosterone. Corticosterone monoacetate was oxidized with chromic trioxide for 5 minutes and converted to 11-dehydrocorticosterone acetate. This compound was chromatographed for 14 to 16 hours in a cyclohexane: benzene: methanol: water (100:40:

TABLE I

Evidence of specificity of the double isotope derivative assay procedure for aldosterone

\begin{tabular}{|c|c|c|c|c|c|}
\hline \multirow{2}{*}{$\begin{array}{l}\text { No. of } \\
\text { sample }\end{array}$} & \multirow[b]{2}{*}{ Source of adrenal vein plasma } & \multicolumn{4}{|c|}{$\mathrm{H}^{3} / \mathrm{C}^{14}$ ratios after each chromatography } \\
\hline & & 1 st & 2nd & 3rd & 4 th \\
\hline 1 & Chronic caval constriction & 20.3 & 1.44 & 0.47 & 0.74 \\
\hline 2 & Chronic caval constriction & 54.4 & 9.48 & 7.93 & 8.26 \\
\hline 3 & Chronic caval constriction & 44.7 & 16.38 & 15.67 & 17.20 \\
\hline 4 & Chronic caval constriction & 4.8 & 0.80 & 0.52 & 0.68 \\
\hline 5 & Normal & 14.6 & 0.54 & & 0.68 \\
\hline 6 & Chronic caval constriction and cortisone & 27.2 & 7.08 & 7.22 & 6.84 \\
\hline 7 & Chronic caval constriction and cortisone & 20.0 & 2.77 & 1.90 & 1.62 \\
\hline 8 & Chronic caval constriction and cortisone & 14.4 & 1.81 & 0.68 & 0.59 \\
\hline 9 & Chronic caval constriction and cortisone & 12.1 & 0.76 & 0.46 & 0.44 \\
\hline 10 & $\begin{array}{l}\text { Chronic caval constriction after hypo- } \\
\text { physectomy and during ACTH }\end{array}$ & 27.3 & 10.53 & 9.46 & 10.00 \\
\hline
\end{tabular}



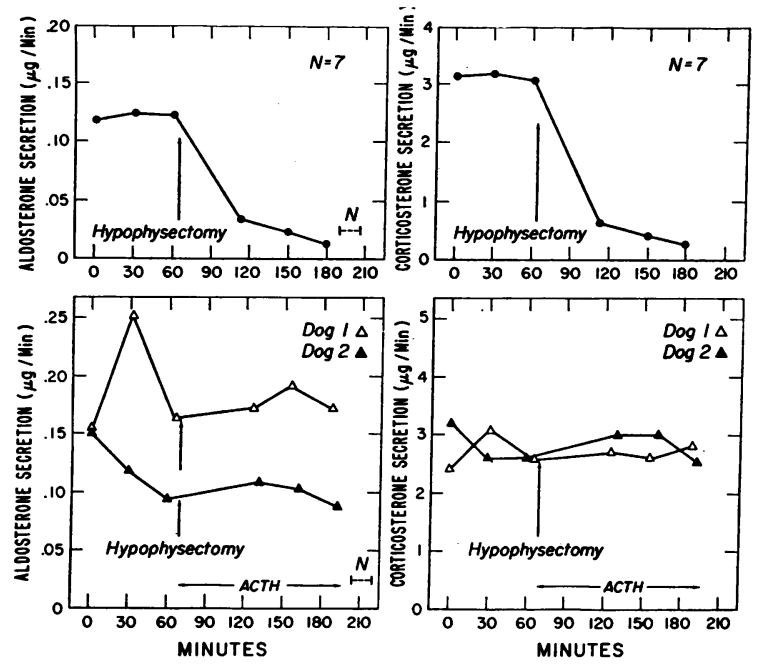

Fig. 1. EFFECTS OF HYPOPHYSECTOMY (UPPER FIGURES) AND THE BLOCKING EFFECTS OF ACTH (0.075 UNIT PER MINUTE) FOLLOWING HYPOPHYSECTOMY (LOWER FIGURES) IN DOGS WITH THORACIC CAVAL CONSTRICTION AND HYPERALDOSTERONISM. The average value of 0.024 $\mu \mathrm{g}$ per minute for aldosterone secretion in 10 normal dogs is represented by the dotted line with the $\mathrm{N}$ above it in the lower right corners of the figures on the left.

$100: 20)$ system. Because the present data on aldosterone secretion were obtained under different experimental conditions from those reported previously (14), additional evidence on specificity has been provided (Table I). $\mathrm{H}^{3} / \mathrm{C}^{14}$ ratios were determined for aldosterone diacetate as described elsewhere (14), after each of 4 chromatographies on adrenal vein plasma from 4 dogs with chronic thoracic caval constriction, one normal dog, 4 of the dogs with chronic thoracic caval constriction given cortisone, and one dog receiving ACTH. For the fourth chromatography, the second chromatographic system employed for routine aldosterone analysis was used and 2-methyl cortisol was added to provide a visible marker. The chromatogram was developed for 18 hours. The $\mathrm{H}^{3} / \mathrm{C}^{14}$ ratios were not significantly reduced after the third chromatography with the possible exception of sample 7 (Table I). This finding indicates that no $\mathrm{H}^{3}$-labeled impurities were present after the third chromatography.

Hypophysectomy was performed by the oral approach. The pituitary was exposed so that it was visible through the dura mater before the initial prehypophysectomy observations were made. After these observations, the pituitary was removed within a 2 to 3 minute period. In Experiment 3, the base of the pituitary stalk was cauterized to destroy any remnant of the pars tuberalis in the first 6 of the $10 \mathrm{dogs}$; in the remaining $4 \mathrm{dogs}$, hypophysectomy alone was performed. In Experiment 1 , tissue remaining in the sella turcica and the hypothalamus was examined for remnants of adenohypophysis.
RESULTS

Experiment 1. Effects of ACTH following hypophysectomy of dogs with thoracic caval constriction

It has been shown previously (11) that hypophysectomy of dogs with thoracic caval constriction results in a striking fall in the secretion of both aldosterone and corticosterone. In the present experiment, an intravenous infusion of ACTH was given after hypophysectomy of two dogs
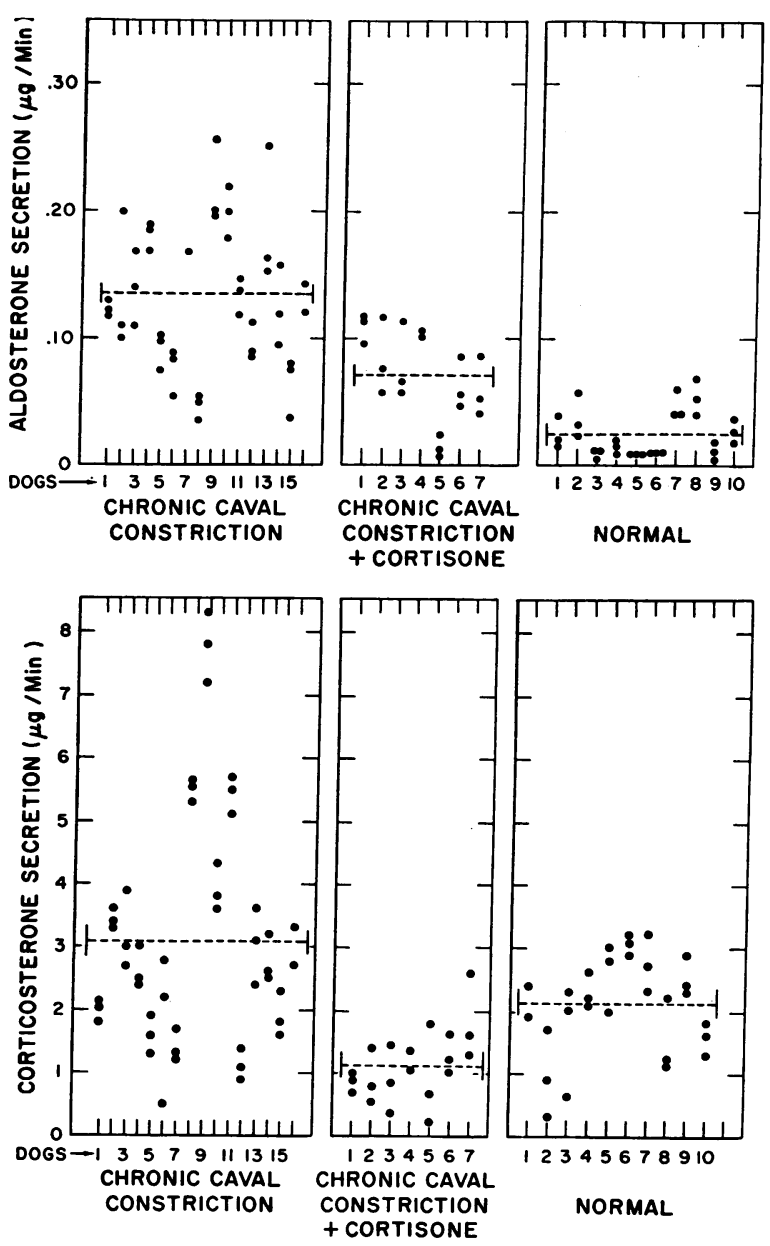

Fig. 2. EFFECT OF CORTISONE (100 MG PER DAY TO DOGS 1 THROUGH 4 AND 200 MG PER DAY TO DOGS 5 THROUGH 7) ON ALDOSTERONE AND CORTICOSTERONE SECRETION IN DOGS WITH CHRONIC THORACIC INFERIOR VENA CAVA CONSTRICTION (CENTER SECTIONS). For comparison, steroid secretion rates in 16 dogs with chronic caval constriction (left sections) and 10 normal dogs (right sections) are presented. The dotted lines show the mean values. 
TABLE II

Aldosterone and corticosterone secretion in dogs with secondary hyperaldosteronism treated with cortisone* : effects of subsequent hypophysectomy $\dagger$ and ACTH†

\begin{tabular}{|c|c|c|c|c|c|c|c|c|}
\hline & \multicolumn{3}{|c|}{ Initial observations } & \multicolumn{3}{|c|}{ After hypophysectomy } & \multicolumn{2}{|c|}{$\underset{\substack{\text { During ACTH } \\
\text { infusion }}}{2}$} \\
\hline & 1 & 2 & 3 & 4 & 5 & 6 & 7 & 8 \\
\hline \multicolumn{9}{|l|}{ Dog 1} \\
\hline $\begin{array}{c}\text { Time, } \min \\
\text { Aldosterone, } \mu g / \min \\
\text { Corticosterone, } \mu g / \min \\
\text { Adrenal blood flow, } \mathrm{ml} / \min \end{array}$ & $\begin{array}{l}0 \\
0.097 \\
0.72 \\
3.88\end{array}$ & $\begin{array}{l}26 \\
0.114 \\
1.00 \\
3.88\end{array}$ & $\begin{array}{l}54 \\
0.120 \\
0.90 \\
3.47\end{array}$ & $\begin{array}{c}117 \\
\quad 0.058 \\
0.37 \\
2.40\end{array}$ & $\begin{array}{l}150 \\
\quad 0.039 \\
0.15 \\
2.18\end{array}$ & $\begin{array}{l}134 \\
\quad 0.030 \\
0.13 \\
2.21\end{array}$ & $\begin{array}{l}220 \\
\quad 0.254 \\
1.3 \\
2.90\end{array}$ & $\begin{array}{l}227 \\
0.248 \\
1.2 \\
3.18\end{array}$ \\
\hline \multicolumn{9}{|l|}{$\operatorname{Dog} 2$} \\
\hline $\begin{array}{c}\text { Time, } \min \\
\text { Aldosterone, } \mu \mathrm{g} / \mathrm{min} \\
\text { Corticosterone, } \mu \mathrm{g} / \mathrm{min} \\
\text { Adrenal blood flow, } \mathrm{ml} / \mathrm{min}\end{array}$ & $\begin{array}{l}0 \\
0.117 \\
1.4 \\
5.27\end{array}$ & $\begin{array}{l}27 \\
0.057 \\
0.60 \\
4.68\end{array}$ & $\begin{array}{l}53 \\
0.076 \\
0.80 \\
3.80\end{array}$ & $\begin{array}{l}123 \\
0.011 \\
0.09 \\
1.65\end{array}$ & $\begin{array}{l}163 \\
0.011 \\
0.05 \\
1.26\end{array}$ & $\begin{array}{l}191 \\
0.013 \\
0.06 \\
1.09\end{array}$ & $\begin{array}{l}251 \\
0.128 \\
0.90 \\
1.42\end{array}$ & \\
\hline \multicolumn{9}{|l|}{ Dog 3} \\
\hline $\begin{array}{c}\text { Time, } \min \\
\text { Aldosterone, } \mu g / \min \\
\text { Corticosterone, } \mu g / \min \\
\text { Adrenal blood flow, } \mathrm{ml} / \mathrm{min}\end{array}$ & $\begin{array}{l}0 \\
0.114 \\
1.43 \\
2.92\end{array}$ & $\begin{array}{l}30 \\
0.065 \\
0.84 \\
3.21\end{array}$ & $\begin{array}{l}59 \\
0.056 \\
0.37 \\
2.72\end{array}$ & $\begin{array}{l}136 \\
0.012 \\
0.029 \\
1.92\end{array}$ & $\begin{array}{l}166 \\
0.013 \\
0.021 \\
1.90\end{array}$ & $\begin{array}{l}197 \\
0.008 \\
0.017 \\
1.76\end{array}$ & $\begin{array}{l}260 \\
0.157 \\
1.38 \\
2.58\end{array}$ & \\
\hline \multicolumn{9}{|l|}{$\operatorname{Dog} 4$} \\
\hline $\begin{array}{c}\text { Time, } \min \\
\text { Aldosterone, } \mu g / \min \\
\text { Corticosterone, } \mu g / \min \\
\text { Adrenal blood flow, } \mathrm{ml} / \min \end{array}$ & $\begin{array}{l}0 \\
0.104 \\
1.36 \\
3.41\end{array}$ & & $\begin{array}{l}54 \\
0.106 \\
1.07 \\
1.75\end{array}$ & & $\begin{array}{l}162 \\
0.039 \\
0.12 \\
1.02\end{array}$ & $\begin{array}{l}196 \\
0.043 \\
0.11 \\
1.04\end{array}$ & $\begin{array}{l}263 \\
0.102 \\
0.94 \\
1.30\end{array}$ & $\begin{array}{l}271 \\
\quad 0.108 \\
1.06 \\
1.38\end{array}$ \\
\hline \multicolumn{9}{|l|}{ Dog 5} \\
\hline $\begin{array}{c}\text { Time, } \min \\
\text { Aldosterone, } \mu \mathrm{g} / \mathrm{min} \\
\text { Corticosterone, } \mu \mathrm{g} / \mathrm{min} \\
\text { Adrenal blood flow, } \mathrm{ml} / \mathrm{min}\end{array}$ & $\begin{array}{l}0 \\
0.012 \\
0.67 \\
4.06\end{array}$ & $\begin{array}{l}31 \\
0.023 \\
1.79 \\
5.87\end{array}$ & $\begin{array}{l}60 \\
0.007 \\
0.22 \\
5.47\end{array}$ & & & & & \\
\hline \multicolumn{9}{|l|}{$\operatorname{Dog} 6$} \\
\hline $\begin{array}{c}\text { Time, } \min \\
\text { Aldosterone, } \mu \mathrm{g} / \mathrm{min} \\
\text { Corticosterone, } \mu \mathrm{g} / \mathrm{min} \\
\text { Adrenal blood flow, } \mathrm{ml} / \mathrm{min}\end{array}$ & $\begin{array}{l}0 \\
0.047 \\
1.00 \\
3.09\end{array}$ & $\begin{array}{l}29 \\
0.084 \\
1.61 \\
3.21\end{array}$ & $\begin{array}{l}52 \\
0.055 \\
1.20 \\
2.40\end{array}$ & $\begin{array}{l}116 \\
\quad 0.004 \\
0.05 \\
2.34\end{array}$ & $\begin{array}{l}144 \\
0.004 \\
0.02 \\
2.29\end{array}$ & $\begin{array}{l}168 \\
0.005 \\
0.01 \\
2.16\end{array}$ & & \\
\hline \multicolumn{9}{|l|}{$\operatorname{Dog} 7$} \\
\hline $\begin{array}{r}\text { Time, } \min \\
\text { Aldosterone, } \mu \mathrm{g} / \mathrm{min} \\
\text { Corticosterone, } \mu \mathrm{g} / \mathrm{min} \\
\text { Adrenal blood flow, } \mathrm{ml} / \mathrm{min}\end{array}$ & $\begin{array}{l}0 \\
0.052 \\
1.63 \\
2.31\end{array}$ & $\begin{array}{l}0 \\
0.042 \\
1.29 \\
2.30\end{array}$ & $\begin{array}{l}25 \\
0.087 \\
2.58 \\
2.84\end{array}$ & & & & & \\
\hline
\end{tabular}

* Dogs 1 through 4 received $100 \mathrm{mg} /$ day of cortisone intramuscularly (i.m.) for 8 days. Dogs 5 through 7 were given $200 \mathrm{mg} /$ day of cortisone i.m. for 7 days; on the eighth day only $100 \mathrm{mg}$ of cortisone was injected i.m. and $100 \mathrm{mg}$ of cortisone was given orally 3 to 5 hours before collection of adrenal vein blood.

t Hypophysectomy was performed immediately after the third period and the ACTH infusion $(0.075 \mathrm{unit} / \mathrm{min})$ was begun after Period 6.

with chronic caval constriction; aldosterone and corticosterone secretion was unaltered. The results are presented in Figure 1 and are compared with the previous finding of decreased steroid secretion following hypophysectomy alone. Histological studies of tissue removed at postmortem examination showed no remaining adenohypophysis in either dog.
Experiment 2. Effects of the chronic daily administration of cortisone on aldosterone and corticosterone secretion in dogs with chronic thoracic caval constriction: subsequent acute effects of hypophysectomy and ACTH

The average value for adrenal vein aldosterone output was 47.3 per cent lower in the seven dogs receiving cortisone (100 to $200 \mathrm{mg}$ per day) than 
in untreated dogs with caval constriction ( $p<$ 0.01 , Figure 2$)$. In one of the animals treated with cortisone (Dog 5, Figure 2), all three determinations of aldosterone were at the normal level. The present data are compared with previous results in 16 dogs with chronic caval constriction. Dogs 5 through 7 received $200 \mathrm{mg}$ per day of cortisone and the average value for aldosterone secretion for these animals was $0.045 \mu \mathrm{g}$ per minute; this value was significantly lower than the average value of $0.135 \mu \mathrm{g}$ per minute for dogs with caval constriction $(p<0.02)$. The rate of aldosterone secretion for the entire group of seven dogs receiving cortisone was significantly greater than the normal level $(p<0.01)$, whereas aldosterone secretion in the three dogs given $200 \mathrm{mg}$ per day of cortisone was not significantly different from normal $(p>0.1)$.

Corticosterone secretion was 63.4 per cent lower (Figure 2) in dogs receiving cortisone than in dogs with caval constriction alone $(\mathrm{p}<0.01)$. Although the response for corticosterone appeared greater than that for aldosterone, the difference was not significant ( $p=0.2$ for the corticosterone:aldosterone ratio). Also, corticosterone output was lower ( 46.5 per cent) in dogs receiving cortisone than in normal dogs studied under the same experimental conditions $(p<0.01)$. The values for corticosterone secretion in both the untreated dogs with caval constriction and normal dogs are probably high and reflect an increased output of ACTH resulting from the "stress" of adrenal vein cannulation. The rates of adrenal blood flow, inferior vena caval pressures and arterial pressures were essentially the same in the dogs with caval constriction in the absence of or during cortisone administration.

Daily $\mathrm{Na}$ balance studies were conducted throughout the period of cortisone administration. Sodium retention continued and $\mathrm{Na}$ excretion was less than $5 \mathrm{mEq}$ per day on the day before sacrifice for adrenal vein blood studies in all but one animal (Dog 7); in this animal, $\mathrm{Na}$ excretion was $17 \mathrm{mEq}$ per day.

Immediately following the initial observations on the cortisone-treated dogs, hypophysectomy was performed in five of the seven dogs and studies were continued for another two hours. A further marked drop in both aldosterone and corticosterone secretion occurred (Table II). Adrenal blood flow was reduced in four of the five dogs. After the post-hypophysectomy observations, an infusion of $\mathrm{ACTH}$ was given to four of the five animals. Adrenal vein aldosterone output increased 8-, 10-, 20- and 2.4-fold with respect to the post-hypophysectomy level in Dogs 1 through 4, respectively, while corticosterone secretion increased 10-, 15-, 81- and 8-fold during the same periods.

\section{Experiment 3. Effects of $\alpha$ - and $\beta-M S H$ on aldo- sterone and corticosterone secretion}

Synthetic $\alpha$-MSH $(4.75 \mathrm{mg}$ ) was assayed in a simple hypophysectomized dog; aldosterone and

TABLE III

Failure of synthetic $\alpha-M S H$ and naturally occurring $\beta$-MSH to increase aldosterone and corticosterone secretion in hypophysectomized dogs

\begin{tabular}{cccc}
\hline \hline & Time & $\begin{array}{c}\text { Aldosterone } \\
\text { secretion }\end{array}$ & $\begin{array}{c}\text { Corticosterone } \\
\text { secretion }\end{array}$ \\
\hline Control & $\min$ & $\mu g / \min$ & $\begin{array}{c}\mu g / \min \\
\text { Infusion of } 4.75 \mathrm{mg} \\
\text { of synthetic } \alpha \text {-MSH }\end{array}$ \\
After & 0 & 0.010 & 0.09 \\
$\alpha$-MSH & $30-60$ & 0.015 & \\
Control & 60 & & 0.15 \\
Infusion of 7 mg of & 90 & $<0.005$ & 0.03 \\
natural $\beta$-MSH & 0 & $<0.005$ & 0.01 \\
After & 30 & $<0.005$ & 0.01 \\
$\beta$-MSH & $30-60$ & & \\
\end{tabular}



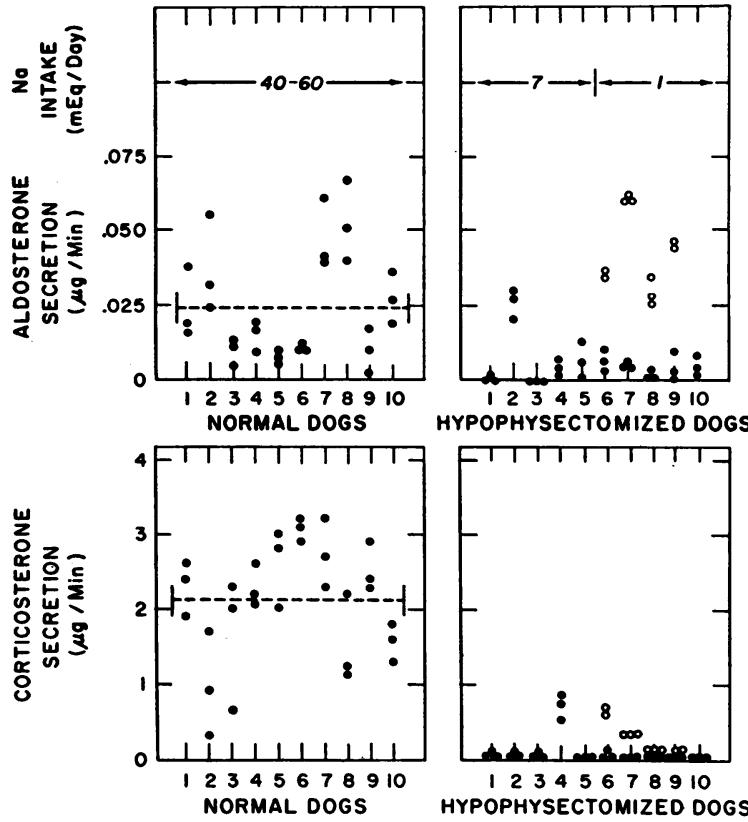

Fig. 3. EFFects of a low Na DIET on aldosterone AND CORTICOSTERONE SECRETION IN TEN SIMPLE HYPOPHYSECTOMIZED DOGS (SOLID SYMBOLS). The open symbols represent values obtained after 30 to 60 minutes of infusion of ACTH (0.075 unit per minute).

corticosterone secretion was unaffected. Highly purified natural hormone preparations of $\alpha$ - and $\beta$-MSH $(2.18 \mathrm{mg}$ of $\alpha$-MSH and 2.0 and $7.0 \mathrm{mg}$ of $\beta$-MSH) were without effect on aldosterone and corticosterone secretion in hypophysectomized dogs. The results of the assays of the two largest quantities of MSH are presented in Table III.

Experiment 4. Failure to produce hypersecretion of aldosterone in simple hypophysectomized dogs

A. With a low salt intake. Of the five dogs on a $\mathrm{Na}$ intake of $7 \mathrm{mEq}$ per day, only one animal showed a secretion rate similar to the average normal value (Figure 3 ); all other values were low. A further reduction in $\mathrm{Na}$ intake to $1 \mathrm{mEq}$ per day also failed to produce a secretion rate comparable to that for normal dogs $(\mathrm{p}<0.01$; no. $=5$ ). Adrenal blood flow was essentially the same in the present hypophysectomized dogs on a low $\mathrm{Na}$ intake as in the normal control animals $(\mathrm{p}>0.2)$. Although aldosterone secretion was lower than normal in hypophysectomized dogs on a low salt intake, the secretion rates for some of these dogs were greater than those in two of the three simple hypophysectomized dogs in which aldosterone was undetectable (compare data in Figure 3 and Table IV). The ability of the adrenal cortex to respond to ACTH in hypophysectomized dogs during $\mathrm{Na}$ deprivation was demonstrated by giving ACTH after the initial observations were complete (Figure 3 ). The rate of aldosterone secretion during infusion of $\mathrm{ACTH}$

TABLE IV

Effects of acute thoracic caval constriction in simple hypophysectomized dogs

\begin{tabular}{|c|c|c|c|c|c|c|}
\hline & Time & $\begin{array}{l}\text { Aldosterone } \\
\text { secretion }\end{array}$ & $\begin{array}{l}\text { Corti- } \\
\text { costerone } \\
\text { secretion }\end{array}$ & $\begin{array}{l}\text { Adrenal } \\
\text { blood } \\
\text { flow }\end{array}$ & $\begin{array}{l}\text { Inferior } \\
\text { vena } \\
\text { caval } \\
\text { pressure }\end{array}$ & $\begin{array}{l}\text { Arterial } \\
\text { pressure }\end{array}$ \\
\hline & $\min$ & $\mu g / \min$ & $\mu g / \min$ & $c c / \min$ & $m m \mathrm{H}_{2} \mathrm{O}$ & $m m \mathrm{Hg}$ \\
\hline $\begin{array}{l}\text { Dog } 1 \\
\text { Control }\end{array}$ & $\begin{array}{r}0 \\
32\end{array}$ & $\begin{array}{l}<0.005 \\
<0.005\end{array}$ & $\begin{array}{l}0.036 \\
0.056\end{array}$ & $\begin{array}{l}2.92 \\
2.58\end{array}$ & $\begin{array}{l}62 \\
55\end{array}$ & $\begin{array}{l}100 \\
104\end{array}$ \\
\hline $\begin{array}{l}\text { Caval constriction } \\
\text { After constriction }\end{array}$ & $\begin{array}{r}37 \\
69 \\
100\end{array}$ & $\begin{array}{l}<0.005 \\
<0.005^{*}\end{array}$ & $\begin{array}{l}0.14 \\
0.15^{*}\end{array}$ & $\begin{array}{l}2.02 \\
2.07^{*}\end{array}$ & $\begin{array}{l}148 \\
188^{*}\end{array}$ & $\begin{array}{l}86 \\
94^{*}\end{array}$ \\
\hline $\begin{array}{c}\text { Dog } 2 \\
\text { Control } \\
\text { Caval constriction }\end{array}$ & $\begin{array}{r}0 \\
27 \\
36\end{array}$ & $\begin{array}{l}<0.005 \\
<0.005\end{array}$ & $\begin{array}{l}0.14 \\
0.13\end{array}$ & $\begin{array}{l}3.53 \\
2.61\end{array}$ & $\begin{array}{l}44 \\
44\end{array}$ & $\begin{array}{l}121 \\
131\end{array}$ \\
\hline After constriction & $\begin{array}{r}96 \\
106\end{array}$ & $\begin{array}{l}<0.005 \\
<0.005\end{array}$ & $\begin{array}{l}0.29 \\
0.25\end{array}$ & $\begin{array}{l}2.50 \\
1.70\end{array}$ & $\begin{array}{l}155 \\
155\end{array}$ & $\begin{array}{r}100 \\
96\end{array}$ \\
\hline $\begin{array}{l}\text { Dog } 3 \\
\text { Control }\end{array}$ & $\begin{array}{r}0 \\
27\end{array}$ & $\begin{array}{l}0.008 \\
0.014\end{array}$ & $\begin{array}{l}0.026 \\
0.029\end{array}$ & $\begin{array}{l}2.00 \\
1.98\end{array}$ & $\begin{array}{l}90 \\
90\end{array}$ & $\begin{array}{l}100 \\
118\end{array}$ \\
\hline $\begin{array}{l}\text { Caval constriction } \\
\text { After constriction }\end{array}$ & $\begin{array}{l}32 \\
57\end{array}$ & 0.009 & 0.111 & 2.81 & 185 & 84 \\
\hline
\end{tabular}

* A norepinephrine infusion $(100 \mu \mathrm{g} / \mathrm{cc})$ was given before and during this collection of adrenal vein blood. 
increased markedly. The initial rate of corticosterone secretion was very low in all animals and the response in corticosterone output to $\mathrm{ACTH}$ was negligible.

$B$. By acute thoracic inferior vena caval constriction. Two hours after hypophysectomy of three normal dogs, the thoracic inferior vena cava was constricted. The degree of constriction and the resultant changes in venous and arterial pressures were similar to those reported (15) for normal dogs following acute caval constriction. Aldosterone and corticosterone output remained unchanged at the low post-hypophysectomy level (Table IV).

\section{DISCUSSION}

Our knowledge of the role of the anterior pituitary in the control of aldosterone secretion and electrolyte metabolism is incomplete. Before aldosterone was discovered, it was recognized that hypophysectomized dogs $(16,17)$ and rats (18) remain in apparently normal electrolyte balance. The experiments of Lane and de Bodo (16) and of Rolf, Surtshin and White (17) demonstrated $\mathrm{Na}$ conservation in hypophysectomized dogs even on a very low $\mathrm{Na}$ intake. Also, hypophysectomized dogs with thoracic caval constriction retained $\mathrm{Na}$ and formed ascites in the presence of a sufficiently elevated venous pressure (1). The finding of Farrell, Rauschkolb and Royce (3) of only a moderately reduced rate of aldosterone secretion following hypophysectomy in the dog was in agreement with earlier studies on electrolyte metabolism.

Other workers, however, have reported a striking fall in aldosterone output following hypophysectomy. In rats, Singer and Stack-Dunne (19) reported an 83 per cent reduction in aldosterone secretion after hypophysectomy. Ganong and associates (20) also found an 83 per cent lower value for aldosterone production in simple hypophysectomized dogs than in normal animals. In experimental secondary hyperaldosteronism in the dog, hypophysectomy resulted in an average reduction of 90 per cent in aldosterone and corticosterone secretion (11). The fall in aldosterone secretion following hypophysectomy of normal anesthetized animals may be exaggerated because of the initial high output which results from the stress of adrenal vein cannulation. However, in unanesthetized dogs with chronic thoracic caval constriction, aldosterone secretion occurs at the same high rate as in anesthetized dogs with caval constriction which are stressed by adrenal vein cannulation (personal observations). The striking drop in aldosterone secretion following hypophysectomy of dogs with thoracic caval constriction emphasizes the important role of the anterior pituitary in the production of aldosterone. Maintenance of a normal electrolyte balance in hypophysectomized dogs in the presence of a low aldosterone output may be the result of the markedly reduced rate of glomerular filtration (21, 22).

In contrast to the situation in the dog, man appears to be fragile. There are several well documented cases of hypopituitarism with salt loss and the resultant clinical features of adrenocortical insufficiency (23). Hernando and associates (7) reported studies of several hypophysectomized patients or patients with hypopituitarism with urinary aldosterone outputs at the lower limit of normal. In one of these patients, a low $\mathrm{Na}$ intake failed to increase urinary aldosterone excretion on two occasions. "The experiments of Llaurado (24) have demonstrated that the increase in urinary aldosterone excretion and the reduction in the urinary $\mathrm{Na} / \mathrm{K}$ ratio were consistently greater after nonendocrinological operations than following total hypophysectomy. . These data indicate that the response in aldosterone production to surgery is less following hypophysectomy, a finding which suggests the necessity of the anterior pituitary for a normal response in aldosterone secretion to surgery.

What anterior pituitary hormones are important in the control of aldosterone secretion? The response to different corticotropin preparations $(3,7,8-10)$ suggests that ACTH influences aldosterone production. The present data show that the 90 per cent drop in aldosterone and corticosterone secretion which follows hypophysectomy was blocked completely by an ACTH preparation. Since the possibility of a contaminating substance in corticotropin preparations cannot be excluded, the effect of inhibition of ACTH secretion on adrenal steroid production was studied. 
In dogs with secondary hyperaldosteronism treated with cortisone, a decrease in both aldosterone and corticosterone secretions occurred in the absence of a detectable change in cardiovascular function. The ACTH content of the adenohypophysis has been demonstrated to be markedly decreased during treatment of normal dogs with similar doses of cortisone and cortisol (25). It appears likely, therefore, that the drop in aldosterone and corticosterone production was secondary to decreased output of ACTH. The data provide more conclusive evidence than those from administration of corticotropin preparations that ACTH plays an important role in aldosterone production. Also, following hypophysectomy and a resultant fall in aldosterone secretion in these ACTH-suppressed dogs, administration of ACTH restored aldosterone and corticosterone output to the very high levels characteristic of dogs with caval constriction. In earlier chronic studies (2), failure of ACTH to prevent the drop in urinary aldosterone excretion following hypophysectomy of dogs with caval constriction seems explicable on the basis of an inadequate level of venous pressure; reconstriction of the thoracic inferior vena cava in these dogs and a resultant further rise in venous pressure was followed by hyperaldosteronuria.

The values for corticosterone secretion in dogs with caval constriction and in normal dogs (Figure 2) are markedly elevated in comparison with the basal rate of corticosterone secretion in trained unanesthetized dogs (personal observations). These high rates of corticosterone secretion reflect the "stress" secondary to adrenal vein cannulation. Hilton and associates (26) reported near maximal output of cortisol in anesthetized dogs during adrenal vein cannulation. Also of interest is the finding of higher values for corticosterone secretion in normal dogs than in the cortisone-treated dogs with caval constriction, while the reverse situation was observed for aldosterone output. These data suggest that the stimulus which increased corticosterone secretion (presumably increased ACTH output) in normal dogs did not similarly influence aldosterone production. The present observations favor the view that ACTH provides important support for steroidogenesis by the adrenal cortex and does not necessarily play an initiative regulatory role in the control of aldosterone secretion. This view is in agreement with the finding of Liddle, Duncan and Bartter (8) that patients with secondary hyperaldosteronism excrete normal amounts of 17 hydroxycorticoids.

In the experiments of Farrell, Banks and Koletsky (25), cortisone and cortisol, $100 \mathrm{mg}$ per day, markedly depressed the ACTH content of the anterior pituitary in normal dogs, and the rates of secretion of cortisol and corticosterone were very low. In contrast, aldosterone secretion was essentially the same in their steroid-treated dogs as in their normal control animals. Their dogs were bled from the adrenolumbar vein over a four hour period. Since bleeding stimulates aldosterone secretion $(27,28)$, it is possible that a fall in aldosterone output was obscured by the effect of bleeding. In the present experiments only 20 to $30 \mathrm{cc}$ of blood was removed for each group of analyses and this was replaced immediately.

The further decrease in aldosterone secretion following hypophysectomy of the cortisonetreated, ACTH-suppressed dogs of the present study raises the question of the influence of anterior pituitary hormones other than $\mathrm{ACTH}$ on aldosterone production. There is, however, the possibility that ACTH secretion was not completely suppressed by cortisone. The present $\alpha$ and $\beta$-MSH preparations had no effect on aldosterone and corticosterone secretion. During chronic balance studies, thyrotropin and growth hormone preparations resulted in marked $\mathrm{Na}$ retention in hypophysectomized dogs with thoracic caval constriction, and discontinuation of both hormones was followed by increased $\mathrm{Na}$ excretion (1). It was suggested (1) that the effects of both thyrotropin and growth hormone were at least partially indirect and mediated through an increase in venous pressure which occurred concurrently with the $\mathrm{Na}$ retention. Canter and coworkers (29) have recently reported that thyroidectomy resulted in a $\mathrm{Na}$ diuresis in dogs with thoracic caval constriction and ascites. Conclusive evidence for a direct effect of thyrotropin and growth hormone is lacking and there is evidence to the contrary for growth hormone (5). Finally, it should be pointed out that another highly active ACTH-like anterior pituitary hormone with potent effects on aldosterone secretion is a possibility. 
The marked effects of hypophysectomy and the importance of ACTH in aldosterone production raise the question of the capacity of the adrenal cortex to secrete increased amounts of aldosterone in the absence of adequate anterior pituitary function. The secretion rates for aldosterone in the present chronic simple hypophysectomized dogs on a low $\mathrm{Na}$ intake were below the normal level. The duration of the low $\mathrm{Na}$ intake was greater than that required for a response in normals to altered electrolyte intake $(8,30,31)$. Several of these low values for aldosterone secretion in hypophysectomized dogs on a low $\mathrm{Na}$ intake were slightly higher, however, than aldosterone secretion in the two of the three dogs which were on a normal $\mathrm{Na}$ intake and aldosterone output was measured two hours after hypophysectomy (Table IV). This finding may indicate some adrenocortical stimulation by the low $\mathrm{Na}$ diet in the simple hypophysectomized dogs. Corticosterone output was extremely low and apparently unaffected by the low $\mathrm{Na}$ diet. These observations are in agreement with the earlier reports of Singer and Stack-Dunne (19) and Eisenstein and Hartroft (32) that a low $\mathrm{Na}$ diet increased aldosterone production in normal rats while corticosterone output was unaltered or declined. Also, Rosnagle and Farrell (33) found no influence of a low $\mathrm{Na}$ diet on cortisol output in normal dogs whereas aldosterone secretion was doubled.

Following acute thoracic caval constriction of simple hypophysectomized dogs, aldosterone secretion failed to increase with essentially the same alterations in cardiovascular function as those produced previously in normal dogs (15). In normal dogs, caval constriction consistently increased aldosterone secretion (15). The data agree with the finding (11) that the acute effect of hypophysectomy in dogs with hyperaldosteronism is a marked fall in aldosterone secretion. In previous chronic experiments (2) it was found, however, that increased aldosterone output in urine and presumably an elevated level of circulating aldosterone occurred frequently in association with marked $\mathrm{Na}$ retention and ascites in hypophysectomized dogs with caval constriction. More recently, chronic studies of conscious hypophysectomized dogs with caval constriction (personal observations) have demonstrated that aldosterone secretion, although markedly reduced, remains sufficiently elevated to explain the associated hyperaldosteronuria and $\mathrm{Na}$ retention. These data, then, provide evidence of hypersecretion of aldosterone in the absence of the anterior pituitary and, thereby suggest an extra-pituitary origin for the aldosterone stimulating hormone, demonstrated previously by cross circulation experiments (14).

The present results are consistent with certain studies and proposed schema for the biogenesis of aldosterone in vitro from glomerulosa slices (34). Ayres and associates (34) have proposed that corticosterone is the immediate precursor to aldosterone in the major pathway of aldosterone synthesis; under certain experimental circumstances 50 to 92 per cent of aldosterone produced in vitro was derived from corticosterone. In the present study, there was a striking similarity in the changes in aldosterone secretion and corticosterone secretion following hypophysectomy and during ACTH administration to hypophysectomized dogs with caval constriction. During cortisone suppression of ACTH secretion, both aldosterone and corticosterone production fell in dogs with caval constriction. During ACTH administration to hypophysectomized dogs on a low $\mathrm{Na}$ intake, corticosterone output failed to increase while aldosterone production reached the upper limit of the normal range. These results may reflect inadequate substrate (precursors) for corticosterone production due to the chronic effects of hypophysectomy and atrophy of the zona fasciculata and reticularis. Sufficient corticosterone (if it is the precursor for aldosterone) was present for conversion to aldosterone and this presumably occurred in the zona glomerulosa. Although corticosterone secretion was markedly reduced in the present hypophysectomized dogs on a low $\mathrm{Na}$ diet the concentration of corticosterone in adrenal vein plasma was several times higher than that of aldosterone so that increased aldosterone production by ACTH might have occurred by conversion of corticosterone to aldosterone.

\section{SUMMARY AND CONCLUSIONS}

An ACTH preparation given following hypophysectomy of two dogs with thoracic caval con- 
striction and hyperaldosteronism prevented the usual fall in aldosterone and corticosterone secretion which follows anterior pituitary ablation. To inhibit ACTH secretion, 100 to $200 \mathrm{mg}$ per day of cortisone was given for eight days to seven dogs with experimental secondary hyperaldosteronism. Aldosterone and corticosterone production was significantly lower than in dogs with chronic ascites without cortisone therapy, and in one of the animals aldosterone output was depressed to normal. Subsequent hypophysectomy of five of these seven ACTH-suppressed dogs resulted in a further decline in aldosterone and corticosterone output. In four of these five animals subjected to hypophysectomy, the ACTH preparation increased aldosterone and corticosterone secretion to or above the control levels. In simple hypophysectomized dogs, $\alpha$ - and $\beta$-MSH were without effect on aldosterone and corticosterone secretion. Attempts to produce hypersecretion in simple hypophysectomized dogs failed: 1) adrenal vein aldosterone output was significantly lower than normal in ten simple hypophysectomized dogs during maintenance on a low $\mathrm{Na}$ diet; 2 ) in three simple hypophysectomized dogs, acute thoracic caval constriction failed to produce an increase in aldosterone secretion. Although aldosterone output was lower in the hypophysectomized dogs on a low $\mathrm{Na}$ intake than in normal dogs on normal electrolyte intake, the data suggest some adrenocortical stimulation in the absence of the anterior pituitary. The response in aldosterone secretion to the ACTH preparation in simple hypophysectomized dogs on a low $\mathrm{Na}$ diet was striking, whereas the increase in corticosterone production was slight. It is concluded that the anterior pituitary plays an important role in the increased production of aldosterone in experimental secondary hyperaldosteronism. It seems likely that ACTH supports steroidogenesis at a very high level.

\section{REFERENCES}

1. Howell, D. S., Davis, J. O., and Laqueur, G. L. Effect of hypophysectomy on electrolyte excretion in dogs with ascites produced by thoracic inferior vena cava constriction. Circulat. Res. 1955, 3, 264.

2. Davis, J. O., Bahn, R. C., Goodkind, M. J., and Ball, W. C., Jr. Aldosterone excretion in urine from hypophysectomized dogs with thoracic inferior vena cava constriction. Amer. J. Physiol. 1957, 191, 329.

3. Farrell, G. L., Rauschkolb, E. W., and Royce, P. C. Secretion of aldosterone by the adrenal of the dog. Effects of hypophysectomy and ACTH. Amer. J. Physiol. 1955, 182, 269.

4. Gaunt, R., Renzi, A. A., and Chart, J. J. Aldosterone-A review. J. clin. Endocr. 1955, 15, 621.

5. August, J. T., Nelson, D. H., and Thorn, G. W Aldosterone. New Engl. J. Med. 1958, 259, 917.

6. Luetscher, J. A., Jr., and Axelrad, B. J. Sodiumretaining corticoid in the urine of normal children and adults and of patients with hypoadrenalism or hypopituitarism. J. clin. Endocr. 1954, 14, 1086.

7. Hernando, L., Crabbé, J., Ross, E. J., Reddy, W. J., Renold, A. E., Nelson, D. H., and Thorn, G. W. Clinical experience with a physico-chemical method for estimation of aldosterone in urine. Metabolism 1957, 6, 518.

8. Liddle, G. W., Duncan, L. E., Jr., and Bartter, F. C. Dual mechanism regulating adrenocortical function in man. Amer. J. Med. 1956, 21, 380.

9. Farrell, G. L., Fleming, R. B., Rauschkolb, E. W., Yatsu, F. M., McCally, M., and Anderson, C. H. Steroidogenic properties of purified corticotropins. Endocrinology 1958, 62, 506.

10. Muller, A. F., Riondel, A. M., and Manning, E. L. Effect of corticotropin on secretion of aldosterone. Lancet 1956, 271, 1021.

11. Davis, J. O., Bahn, R. C., Yankopoulos, N. A., Kliman, B., and Peterson, R. E. Acute effects of hypophysectomy and diencephalic lesions on aldosterone secretion. Amer. J. Physiol. 1959, 197, 380.

12. Davis, J. O., and Howell, D. S. Mechanisms of fluid and electrolyte retention in experimental preparations in dogs. II. With thoracic inferior vena cava constriction. Circulat. Res. 1953, 1, 171.

13. Davis, J. O., Pechet, M. M., Ball, W. C., Jr., and Goodkind, M. J. Increased aldosterone secretion in dogs with right-sided congestive heart failure and in dogs with thoracic inferior vena cava constriction. J. clin. Invest. 1957, 36, 689.

14. Yankopoulos, N. A., Davis, J. O., Kliman, B., and Peterson, R. E. Evidence that a humoral agent stimulates the adrenal cortex to secrete aldosterone in experimental secondary hyperaldosteronism. J. clin. Invest. 1959, 38, 1278.

15. Davis, J. O., Kliman, B., Yankopoulos, N. A., and Peterson, R. E. Increased aldosterone secretion following acute constriction of the inferior vena cava. J. clin. Invest. 1958, 37, 1783.

16. Lane, N., and de Bodo, R. C. Generalized adrenocortical atrophy in hypophysectomized dogs and correlated functional studies. Amer. J. Physiol. 1952, 168, 1.

17 Rolf, D., Surtshin, A., and White, H. L. Sodium conservation in normal and hypophysectomized dogs. Amer. J. Physiol. 1952, 169, 576. 
18. Greep, Roy O. Preliminary observations on the relation of the adrenal cortex to electrolyte metabolism in the rat. Pituitary-adrenal function. Amer. Ass. Sci. 1950, p. 96.

19. Singer, B., and Stack-Dunne, M. P. The secretion of aldosterone and corticosterone by the rat adrenal. J. Endocrin. 1955, 12, 130.

20. Ganong, W. F., Lieberman, A. H. Daily, W. J. R., Yuen, V. S., Mulrow, P. J., Luetscher, J. A., Jr., and Bailey, R. E. Aldosterone secretion in dogs with hypothalamic lesions. Endocrinology 1959, $65,18$.

21. White, H. L., Heinbecker, P., and Rolf, D. Some endocrine influences on renal function and cardiac output. Amer. J. Physiol. 1947, 149, 404

22. Goodkind, M. J., Davis, J. O., Ball, W. C., Jr., and Bahn, R. C. Alterations in cardiovascular and renal hemodynamic function following hypophysectomy in the dog. Amer. J. Physiol. 1957, 188, 529.

23. Stephens, D. J. Chloride excretion in hypopituitarism with reference to adrenocortical function. Amer. J. med. Sci. 1940, 199, 67.

24. Llaurado, J. G. Aldosterone excretion following hypophysectomy in man: Relation to urinary $\mathrm{Na} / \mathrm{K}$ ratio. Metabolism 1957, 6, 556.

25. Farrell, G. L., Banks, R. C., and Koletsky, S. The effect of corticosteroid injection on aldosterone secretion. Endocrinology 1956, 58, 104.

26. Hilton, J. G., Weaver, D. C., Muelheims, G., Glaviano, V. V., and Wegria, R. Perfusion of the iso- lated adrenals in situ. Amer. J. Physiol. 1958, 192, 525.

27. Farrell, G. L., Rosnagle, R. S., and Rauschkolb, E. W. Increased aldosterone secretion in response to blood loss. Circulat. Res. 1956, 4, 606.

28. Goodkind, M. J., Ball, W. C., Jr., and Davis, J. O. Effect of chronic hemorrhage on urinary aldosterone-like activity and sodium excretion in dogs. Amer. J. Physiol. 1957, 189, 181.

29. Canter, J. W., Kreel, I., Segal, R. L., Frankel, A., and Baronofsky, I. D. Influence of thyroidectomy on experimental ascites. Proc. Soc. exp. Biol. (N. Y.) 1959, 100, 771.

30. Combined staff clinic. Mechanisms of edema formation and principles of management. Amer. J. Med. 1956, 21, 423.

31. Luetscher, J. A., Jr., and Axelrad, B. J. Increased aldosterone output during sodium deprivation in normal men. Proc. Soc. exp. Biol. (N. Y.) 1954, 87, 650.

32. Eisenstein, A. B., and Hartroft, P. M. Alterations in rat adrenal cortex induced by sodium deficiency: Steroid hormone secretion. Endocrinology 1957, 60, 634.

33. Rosnagle, R. S., and Farrell, G. L. Alterations in electrolyte intake and adrenal steroid secretion. Amer. J. Physiol. 1956, 187, 7.

34. Ayres, P. J., Eichborn, J., Hechter, O., Saba, N., Tait, J. F., and Tait, S. A. S. Some studies on the biosynthesis of aldosterone and other adrenal steroids. Acta endocr. (Kbh.) 1960, 33, 27. 